Başol, O. ve Çömlekçi, M. F. (2021). “Uzaktan Çalışmanın Sosyal ve Demografik Değişkenlerle iliş̧isi Üzerine Bir Araştırma", Eskişehir Osmangazi Üniversitesi iiBF Dergisi, 16(3), 755 - 776.

Doi: 10.17153/oguiibf.941442

Başvuru: 23.05.2021 Kabul: 14.08.2021

Araştırma Makalesi/Research Article

\title{
Uzaktan Çalışmanın Sosyal ve Demografik Değişkenlerle iliş̧kisi Üzerine Bir Araştırma
}

\begin{tabular}{|c|c|}
\hline & $\begin{array}{l}\text { Oğuz Başol }{ }^{1} \text { (iD) } \\
\text { Mehmet Fatih Çömlekçi (iD) }\end{array}$ \\
\hline $\begin{array}{l}\text { Uzaktan Çalışmanın Sosyal ve Demografik Değişkenlerle } \\
\text { ilişkisi Üzerine Bir Araştırma }\end{array}$ & $\begin{array}{l}\text { A Research on Remote Working and Its Relation with } \\
\text { Social and Demographic Variables }\end{array}$ \\
\hline Öz & Abstract \\
\hline $\begin{array}{l}\text { Covid-19 pandemisi döneminden uzaktan çalışma } \\
\text { uygulamaları yaygın olarak deneyimlenmiştir. Mevcut } \\
\text { çalışmanın amacı, uzaktan çalışma tutumu üzerinde } \\
\text { etkisi olan sosyal ve demografik belirleyicileri ortaya } \\
\text { koymak ve uzaktan çalışmanın geleceği ile ilgili bazı } \\
\text { öneriler getirmektir. Araştırma kapsamında, Türkiye'nin } \\
\text { farklı bölgelerindeki } 415 \text { beyaz yakalı ve uzaktan çalışma } \\
\text { deneyimi bulunan kişiden anket tekniğiyle veri } \\
\text { toplanmış, nicel yöntemsel yaklaşım benimsenmiştir. } \\
\text { Elde edilen veriler SPSS } 22 \text { paket programı ile analiz } \\
\text { edilmiştir. Araştırma sonucunda, eğitim seviyesi daha } \\
\text { yüksek olan beyaz yakalı çalışanların uzaktan çalışmaya } \\
\text { karşı daha olumlu tutum geliştirdikleri görülmüştür. Öte } \\
\text { yandan, uzaktan çalışma ile çalışanlarının iş yükünün } \\
\text { arttığı durumlarda, çalışanların uzaktan çalışmaya karşı } \\
\text { daha olumsuz bir yaklaşım geliştirdikleri görülmüştür. } \\
\text { Organizasyonların iş yükünü kontrol altında tutup } \\
\text { dengelemeden uzaktan çalışmaya geçmelerinin onlar } \\
\text { açısından negatif sonuçlar doğurabileceği } \\
\text { anlaşılmaktadır. }\end{array}$ & $\begin{array}{l}\text { Remote working has been widely experienced, especially } \\
\text { during the Covid- } 19 \text { pandemic. The present study aims } \\
\text { to reveal the social and demographic determinants that } \\
\text { have an impact on remote work attitudes and to make } \\
\text { some recommendations about the future of remote } \\
\text { work. We collected the data from } 415 \text { white-collar and } \\
\text { remotely working people in different regions of Turkey } \\
\text { by using the questionnaire method. We analyzed the } \\
\text { collected data with the SPSS } 22 \text { package program. As a } \\
\text { result, we observed that white-collar employees with } \\
\text { higher education levels develop a more positive attitude } \\
\text { towards remote working. On the other hand, when the } \\
\text { workload of the employee increases with the remote } \\
\text { working, they tend to employ a more negative approach } \\
\text { towards remote working. If the organizations switch to } \\
\text { remote working without controlling and balancing the } \\
\text { workload, they may face negative consequences. }\end{array}$ \\
\hline $\begin{array}{l}\text { Anahtar Kelimeler: Uzaktan Çalışma, Covid-19, Çalışma } \\
\text { Psikolojisi }\end{array}$ & Keywords: Remote Working, Covid-19, Work Psychology \\
\hline JEL Kodları: C83, J24, J81 & JEL Codes: C83, J24, J81 \\
\hline \multicolumn{2}{|c|}{$\begin{array}{c}\text { Araştırma ve } \\
\begin{array}{c}\text { Yayın Etiği çalışma 20/11/2020 tarih ve 35523585-199-E.17402 sayılı Kırklareli Üniversitesi Bilimsel Araştırmalar ve Yayın } \\
\text { Beyanı }\end{array} \\
\text { Etiği Kurulu Onay Belgesi ile bilimsel araştırma ve yayın etiği kurallarına uygun olarak hazırlanmıştır. }\end{array}$} \\
\hline Yazar 1'in makaleye katkısı \%50, Yazar 2'nin mak & leye katkısı \%50'dir. \\
\hline Yazarlar açısından ya da üçüncü taraflar açısında & çalışmadan kaynaklı çıkar çatışması bulunmamaktadır. \\
\hline
\end{tabular}

\footnotetext{
${ }^{1}$ Doç. Dr., Kırklareli Üniversitesi, İktisadi ve İdari Bilimler Fakültesi, Çalışma Ekonomisi ve Endüstri İlişkileri Bölümü, oguzbasol@klu.edu.tr

${ }^{2}$ Doç. Dr., Kırklareli Üniversitesi, Rektörlük, fatihcomlekci@gmail.com
} 


\section{Giriş}

Uzaktan çalışma uygulamaları, "Çalışma hayatının geleceğinde ne var?” tartışmalarının merkezinde yer almaya devam etmektedir. Hızlı bir dijitalleşme ile yeni mobil iletişim teknolojilerinin gündelik hayatı ve çalışma hayatını dönüşüme uğrattığı günümüzde, zaman ve mekân kısıtlarını esneten iş model ve uygulamaları da yaygınlaşmaktadır. Şirketler fiziki altyapı giderleri gibi çeşitli maliyetleri düşürmesi ve üretkenliği arttırması; özellikle beyaz yaka çalışanlar ise ulaşım güçlüklerinin ortadan kalkması ve daha bağımsız bir zaman yönetimini mümkün kılması gibi çeşitli sebeplerle uzaktan çalışmaya karşı olumlu bir tutum geliştirebilmektedirler. Bu genel eğilimlere 2020 yılı başlarında dünyayı etkisi altına almaya başlayan Covid-19 Pandemisinin hem kamuda hem de özel sektörde neden olduğu "zorunlu" uzaktan çalışma uygulamaları eklendiğinde, çalışma hayatının geleceği ile ilgili tartışmalarda uzaktan çalışmanın, dijitalleşmenin ve yeni teknoloji uygulamalarının belirleyici rolü daha net bir biçimde ortaya çıkmaktadır.

Güncel bir araştırmaya göre, dünya çapında şirketlerin yaklaşık \%56'sı uzaktan çalışma uygulamalarını benimsemişken $\% 16$ 'sı tüm operasyonlarını uzaktan çalışma ile gerçekleştirmektedir. Çalışanların ise \%52'si haftada en az bir kere, \%68'ı ayda en az bir kere uzaktan çalıştıklarını ifade etmektedirler (Owl Labs, 2021). McKinsey'in araştırmasına göre de gelişmiş ekonomilerdeki çalışanların \%20-25'i, gelişmekte olan ekonomilerdeki çalışanların ise yaklaşık \%10'u haftanın beş günü uzaktan çalışmaya uygun işlerde çalıştıklarından, bu çalışma biçiminin pandemi sonrasında pandemi öncesine göre daha yaygın biçimde uygulanacağı düşünülmektedir. Uzaktan çalışma, mobil telefon ve internet teknolojilerindeki gelişmeler sayesinde, uzun yıllardır mümkün olmakla ve bazı sektörlerde uygulanmakla birlikte küresel anlamda yaygınlaşamamıştır (Wang vd., 2021: 17). Ancak pandemi dönemindeki zorunluluklardan kaynaklı olarak uzaktan çalışmanın etkisi yaygınlaşmış; video konferans, yeni nesil doküman paylaşım uygulamaları ve bulut teknolojilerindeki yeni dijital çözümler bu süreci ivmelendirmiştir (Lund vd., 2021: 5-6). İnsanlar işlerinin tamamını çevrimiçi ortamda halletmeseler bile video konferans araçlarını toplantı yapmak, meslektaşlarıyla iletişim halinde kalmak ve sosyal ağlarını genişletmek gibi amaçlarla sıklıkla kullanmaya başlamışlardır (Das vd., 2021: 3). Her türden dijital uygulamanın ve uzaktan çalışmanın pandemi süreciyle birlikte yaygınlaşması, çalışanların bu çalışma biçime karşı geliştirdikleri tutumların ve bu tutumları etkileyen çeşitli faktörlerin araştırılması ihtiyacını doğurmuştur.

Çalışmanın amacı, uzaktan çalışma tutumu üzerinde etkisi olan sosyal ve demografik belirleyicileri ortaya koymak, bu kapsamda özellikle Covid-19 Pandemisi döneminde artan uzaktan çalışma uygulamalarının geleceği ile ilgili bir tartışma zemini yaratmak ve eldeki veriler kapsamında bazı öneriler getirmektir. Hangi şart ve koşulların altında uzaktan çalışmaya karşı olumlu bir tutum geliştirilebileceğini tespit etmenin, önümüzdeki süreçteki uzaktan çalışma uygulamaları bağlamında hem çalışan hem de işveren açısından yol gösterici olacağına inanılmaktadır. 


\section{Uzaktan Çalışmaya ve Literatüre Genel Bakış}

Uzaktan çalışma kavramı, telekomünikasyon, bilişim ve internet gibi teknolojileri kullanarak geleneksel ofis ortamı dışından çalışmayı işaret etmektedir. Erken tanımlardan birinde uzaktan çalışma, "çalışanların merkez ofis ya da üretim tesisi gibi yerlerden ve çalışma arkadaşlarından mekânsal olarak ayrı olduğu, ancak teknolojik cihazlar sayesinde onlarla iletişimde kaldığı esnek çalışma biçimi” olarak çerçevelenmiştir (Di Martino ve Wirth, 1990: 530). Çalışma mekânı ev olabileceği gibi sadece bununla sınırlı değildir ve kafeler, ortak çalışma alanları, hatta parklar bile uzaktan çalışma için kullanılabilir. Mobil akıllı telefon, tablet, taşınabilir bilgisayar ve internet bağlantısı gibi teknolojik olanaklara erişim, bu çalışma biçimi için gereken altyapıyı da sağlamaktadır. Bu noktada kurumların/şirketlerin gerekli teknolojik altyapı ve oryantasyon programlarına sahip olmaları ve beyaz yaka çalışanların da dijital becerilerini geliştirmeleri kritik hale gelmektedir.

Çalışanlar uzaktan çalışma uygulamaları ile özel/aile yaşamlarına daha fazla zaman ayırabilme olanağına ve çalışma saatleri/günleri anlamında görece bir esnekliğe kavuşmaktadır. Uzaktan çalışmanın pozitif yönlerine dikkat çeken çalışmaların bir bölümü, artan esneklikle birlikte üretkenliğin de arttığı yönünde bulgulara ulaşmıştır (Allen vd., 2015; Bloom vd., 2015; Hunter, 2019; Choudhury vd., 2021). Ayrıca uzaktan çalışmanın iş-yaşam dengesini iyileştirebileceği (Sullivan, 2012; Vartiainen, 2012; Putra vd., 2020), aile üyeleriyle daha çok zaman geçirmeyi sağlayarak aile bağlarını güçlendirebileceği (Putnam vd., 2014), iş tatminini arttırırken tükenmişlik hissini önleyebildiği (Felstead ve Henseke, 2017; Schall, 2019), işe geliş-gidişten kaynaklanan stresi ortadan kaldırdığı (Vartiainen, 2012), iş motivasyonunu pozitif etkilediği (Verburg vd., 2013) ve çalışanın özerkliğini/bağımsızlığını arttırdığı (Vartiainen, 2012; Mattarelli ve Tagliaventi, 2010) yönünde araştırmalar bulunmaktadır. İşveren perspektifinden bakıldığında ise, literatürde uzaktan çalışma uygulamalarının çeşitli şirket giderlerini (ofis, fiziki altyapı, ulaşım, beslenme vb. masraflar) düşürdüğü hususu üzerinde ısrarla durulduğu görülmektedir (Sundin, 2008; Ferreira vd., 2021).

Öte yandan, bu çalışma biçiminin sosyal etkileşimi azaltarak izole bir yaşamı tarzını ve yalnızlığı tetikleyebileceği (Grant vd., 2013; Allen vd., 2015; Moss, 2018; Thompson, 2018), iş yükünü ve dolayısıyla stresi arttırabileceği (Mihhailova, 2009; Golden ve Eddleston, 2020), organizasyonel ve teknik yetersizlikler dolayısıyla iş tatminini düşürebileceği (Mihhailova vd., 2011), iş, yaşam ve özel hayatla ilgili çatışmaları arttırabileceği (Webster ve Randle, 2016; Flores, 2019) ve zaman yönetimini güçleştirebileceği (Beise vd., 2010; Mihhailova vd., 2011) gibi olumsuz hususlar da gündeme getirilmiştir. Covid-19 Pandemisi döneminde özellikle işyaşam dengesinin olumsuz biçimde etkilendiği (Palumbo, 2020; Bellmann ve Hübler, 2020) ve işleri dijital çalışma ortamına uygun olmayan dezavantajı kesimlerin de süreçten zararlı çıktığı (Bozkurt, 2020: 105) yönünde çalışmalar da bulunmaktadır. İşveren perspektifinden bakıldığında ise, teknolojik altyapı ve yazılım sorunları ile buna bağlı olarak gelişebilecek iletişim problemlerinin literatürde sıklıkla tartışıldığı görülmektedir (Sivunen vd., 2016; Vartiainen ve Andriessen, 2006).

Ayrıca dijital teknolojiler sayesinde "her zaman" ağa bağı olan çalışanın iş yükü artabilmekte (Mazmanian vd., 2013) ve çalışma hayatındaki "esneklik" çalışanın özel yaşamını baskılayarak onu strese sokabilmektedir. Örneğin pandemi boyunca adeta "norm" halini alan uzun saatler boyu süren çevrimiçi toplantıların çalışana yarattığı negatif etkiler, Zoom yorgunluğu olarak adlandırılmaya başlanmıştır (Rogers, 2020). Ayrıca bu çalışma biçiminde 
kişinin kendini disipline edebilmesi zorlaşabilmekte ve şirketlerin dijital teknolojiler ile bu anlamdaki eğitimlere gerekli yatırımı yapmaması sonucunda uzaktan çalışma deneyimi sancılı bir hal alabilmektedir. Bu açıdan bakıldığında, uzaktan çalışmanın olumlu ve olumsuz yanlarını bir arada düşünmek ve konunun işveren ile çalışan açısından farklı sonuçları olabileceğini hesaba katmak gerekmektedir.

Mevcut çalışma ise, uzaktan çalışmanın bu olumlu ya da olumsuz olarak nitelenebilecek boyutlarını, uzaktan çalışmayı etkileyen demografik ve sosyal değişkenler bağlamında ele almaktadır. Tanımlayıcı niteliği sahip olan çalışmada iki araştırma sorusu ileri sürülmüştür:

Araştırma Sorusu 1: Uzaktan çalışmanın demografik değişkenler ile olan ilişkisi nedir?

Araştırma Sorusu 2: Uzaktan çalışmanın sosyal değişkenler ile olan ilişkisi nedir?

\section{Yöntem}

Araştırmanın yöntem kısmında araştırmanın evreni ve örneklemi tanıtılmış, akabinde araştırmada kullanılan veri toplama aracına ilişkin detaylara yer verilmiştir. Araştırmada anket veri toplama tekniğiyle nicel bir yöntemsel yaklaşım benimsenmiştir.

\subsection{Araştırmanın Örneklemi}

Mevcut araştırma Türkiye'nin farklı şehirlerinde yaşayan, kamu ya da özel sektörde istihdam edilen, pandemi döneminde en az bir saat uzaktan çalışma deneyimine sahip olan bireylerin katılımıyla gerçekleştirilmiştir. Veriler çevrimiçi ortamda toplanmış, anketler popüler sosyal medya platformları ve kapalı mesajlaşma grupları üzerinden dağıtılmıştır. Bu sayede uzaktan çalışma tecrübesi bulunan kişilerden anketi doldurmaları istenmiştir. Örnekleme yöntemi olarak kartopu örnekleme yöntemi kullanılmıştır. Daha önceden etik kurul izni alınan anketin bir ay süreyle açık olacağı bilgisi potansiyel katılımcılara iletilmiş ve ilgili süre tamamlandığında 415 anketin gerçekleştirildiği görülmüştür. Anketi gerçekleştirenler öncesinde bir bilgi formuyla bilgilendirilmiş ve onayları alındıktan sonra araştırmaya katılmaları sağlanmıştır. Veri toplama süreci Mart-Nisan 2021 ayları arasında, çevrimiçi anket tekniği kullanılarak gerçekleştirilmiştir.

Katılımcıların \%58.3'ü özel sektör çalışanıdır. Katılımcıların \%56.4'ü kadın ve \%51.3'ü evlidir. Katılımcıların ağırlıklı olarak çocuk sahibi olmadıkları görülmektedir (\%66.3). Katılımcılar en az lisans düzeyinde eğitim almışlardır (\%51.6), diğer katılımcılar ise lisansüstü düzeyinde eğitime sahiptir. Katılımcıların \%73.7'si çalışan statüsündeyken, \%26,3'ü yönetici konumundadır. Katılımcıların yaşları incelendiğinde 22 ile 65 arasında değiştiği ve ortalama

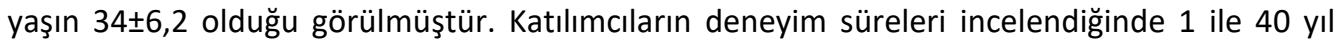

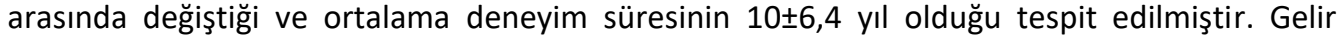
bakımından katılımcılar incelendiğinde gelirin 2200 TL ile 35000 TL arasında değiştiği ve ortalama gelirin $7140 \pm 4078 \mathrm{TL}$ olduğu belirlenmiştir. Haftalık çalışma saatlerinin 10 ile 80 arasında değiştiği ve ortalama haftalık çalışma saatinin $41 \pm 10,8$ olduğu; haftalık uzaktan çalışma süresinin ise 2 saat ile 70 saat arasında değiştiği ve ortalama haftalık uzaktan çalışma süresinin $26 \pm 16,1$ saat olduğu görülmüştür. 


\subsection{Veri Toplama Aracı}

Araştırmada kullanılan veri toplama aracı üç bölümden oluşmaktadır. İlk bölümde katılımcıların demografik özelliklerini sorgulayan 10 soru bulunmaktadır (sektör, cinsiyet, medeni durum, çocuk sahibi olma durumu, eğitim, pozisyon, yaş, deneyim, haftalık çalışma süresi, haftalık uzaktan çalışma süresi). İkinci bölümde katılımcıların uzaktan çalışmaya ilişkin deneyimlerini sorgulamayı hedefleyen 6 soru bulunmaktadır (örneğin, uzaktan çalışma tercihi, uzaktan çalışma sıklığı, uzaktan çalışma sonrası iş yükü durumu, vs.). Üçüncü bölümde ise yazarlar tarafından geliştirilen, geçerlik ve güvenirliği gerçekleştirilmiş ve 16 maddeden oluşan "uzaktan çalışma tutumu" ölçeği yer almaktadır.

Bu ölçeğin soruları, "uzaktan çalışma" ve "remote work" anahtar kelimelerini barındıran eserler taranarak hazırlanmıştır. Sorular hazırlandıktan sonra ölçek maddeleri alanda uzman olan üç öğretim üyesine gönderilmiştir. Böylece uzman görüşleri toplanmış, kişilerden eklemek, çıkartmak ya da düzeltmek istedikleri maddeleri sebepleriyle birlikte belirtmeleri istenmiştir. Gerekli düzenlemeler yapıldıktan sonra ölçeğin son hali ortaya çıkmıştır. Daha sonra, çevrimiçi bir kapalı mesajlaşma platformu üzerinden, uzaktan çalışma tecrübesi bulunan altı kişilik bir grupla odak grup görüşmesi gerçekleştirilmiştir. Grubun sorularla ilgili eleştiri, öneri ve anlaşılırlık düzeyi ile ilgili yorumları alınmış, soruların ifade şekilleriyle ilgili bazı düzenlemeler yapılmıştır. Son olarak bir pilot çalışma gerçekleştirilmiştir. Uzaktan çalışma tecrübesi bulunan 30 kişilik bir gruba çevrimiçi ortamda anket uygulanmıştır, anketin içsel tutarlılık seviyesinin uygun olduğu görülünce, anketin nihai uygulama aşamasına geçilmiştir.

Böylece, geçerlik ve güvenirlik çalışması yazarlar tarafından gerçekleştirilmiş (Kikare/serbestlik değeri: 2,17; RMSEA: 0,06; NFI: 0,97; NNFI: 0,98; CFI: 0,99; GFI: 0,92; AGFI: 0,89 ve Cronbach's Alpha: 0,91 ) ve 16 maddeden oluşan "uzaktan çalışma tutumu" ölçeği ortaya çıkmıştır (örnek madde: Uzaktan çalışma, iş performansımı olumlu etkiledi). Ölçeğin değerlendirmesinde 5 'li likert tipi değerlendirme kullanılmıştır (1: kesinlikle katılmıyorum, 5: kesinlikle katılıyorum).

Araştırmada kullanılan uzaktan çalışma tutumu ölçeği dört alt faktörden oluşmaktadır. Ölçeğin ilk faktörü "Olumlu Tutum” değişkenidir. Bu faktörde dört madde bulunmaktadır ve ilgili faktörden alınan puanın artması, katılımcının uzaktan çalışmaya karşı tutumunun olumlu yönde ilerlemesi anlamına gelmektedir. Ölçeğin ikinci faktörü "Beceri Geliştirme" değişkenidir. Bu faktörde dört madde vardır ve faktör katılımcıların uzaktan çalışma sonrasında gelişen becerilerine odaklanmaktadır ve bu faktörden alınan puanın artması, katılımcıların uzaktan çalışmayla birlikte iletişim, teknoloji ve zaman yönetimi gibi becerilerinin geliştiğini göstermektedir. Ölçeğin üçüncü faktörü "Olumsuz Tutuma Direnç" değişkenidir. Bu faktörde dört madde bulunmaktadır, bu faktör katılımcıların uzaktan çalışmaya ilişkin olumsuz tutumunu ifade etmektedir ve bu faktörden alınan puanın artması, katılımcıların uzaktan çalışmaya ilişkin stres ve çatışma gibi olumsuz tutumlarının azaldığını göstermektedir. Ölçeğin dördüncü faktörü "Kurumsal Destek" değişkenidir. Bu faktörde de dört madde bulunmaktadır, bu faktör katılımcıların çalıştıkları kurumların uzaktan çalışma ilişkin desteğini göstermektedir ve bu faktörden alınan puanın artması, katılımcının çalıştığı kurumun uzaktan çalışma konusunda çalışana daha yüksek destek verdiğini göstermektedir. Ölçek, tüm maddelerin ortalaması alınarak "Uzaktan Çalışma Tutumu" şeklinde değerlendirilmektedir. Ölçekten alınan puanın artması, katılımcının uzaktan çalışmaya karşı olumlu tutumunun arttığını, becerilerin geliştiğini, olumsuz tutumun azaldığını ve kurumsal desteğin arttığını göstermektedir. 


\section{Verilerin Analizi}

Araştırmada elde edilen bulgular iki bölüm olarak tasarlanmıştır. İlk bölümde, uzaktan çalışmaya ilişkin özelliklerin frekanslarına yer verilmiştir. İkinci bölümde ise uzaktan çalışma tutumu ölçeğinin demografik ve uzaktan çalışma özelliklerine göre nasıl şekillendiğine ilişkin analiz sonuçlarına yer verilmiştir. Analizlerin ikinci bölümündeki kısım farklııklara ve ilişkilere odaklandığından ilgili yerde fark testlerine ve korelasyona yer verilmiştir. Ancak yapılan normal dağılım analizi sonrasında verilerin normal dağılım ölçütlerine uymadığı görülmüştür. $\mathrm{Bu}$ nedenle farklılıklar ve ilişkiler için parametrik olmayan test yöntemleri tercih edilmiştir (Mann-Whitney $\mathrm{U}$; Kruskal-Wallis $\mathrm{H}$ ve Spearman korelasyon testi) ve araştırmada verilerin analizi için SPSS 22 paket programı kullanılmıştır.

\subsection{Uzaktan Çalışmaya İlişkin Özellikler}

Daha önce de belirtildiği üzere araştırmaya halihazırda uzaktan çalışma deneyimi olan, en az lisans düzeyinde eğitim almış ve beyaz yakalı olarak çalışan 415 kişi katılmıştır. Bu katılımcıların \%67.2'si uzaktan çalışmayı bir "zorunluluk" olarak değerlendirirken; \%32.8'i uzaktan çalışmayı "kendi tercihi" olarak nitelendirmiştir. Buna göre uzaktan çalışma ağırlıklı olarak zorunlu bir çalışma biçimi olarak kendini göstermektedir.

Katılımcıların uzaktan çalışma sıklığı incelendiğinde; katılımcıların \%41.7'sinin "haftanın belirli günlerinde", \%40.7'sinin "sürekli" ve \%18.1'inin de "ayın belirli günlerinde" uzaktan çalışma gerçekleştirdikleri görülmüştür. Buna göre neredeyse katılımcıların 8/10'u ya sürekli ya da haftanın belirli günlerinde uzaktan çalışmaktadır. Bu durum, uzaktan çalışmanın yaşamın önemli bir parçası haline geldiğini göstermesi bakımından önemlidir.

Önemli özelliklerden biri de uzaktan çalışma sonrası iş yükü durumudur. Buna göre katılımcıların \%42.7'si uzaktan çalışma sonrasında iş yüklerinin "arttığını", \%39.3'ü "aynı kaldığını", \%18.1'i ise "azaldığını" belirtmiştir. Bu durum uzaktan çalışmanın, çalışma hayatındaki yükü alan bir yapıda olmadığının bir göstergesi olarak okunabilir. Nitekim çalışanların \%80'inden fazlasının iş yükü ya artmış ya da aynı kalmıştır. Ancak her beş kişiden birinin iş yükünün azalması uzaktan çalışmanın hem iş yükü hem de iş-yaşam dengesi bakımından incelenmesi gerektiğini göstermektedir.

Ankette sorgulanan durumlardan bir diğeri ise evde anketi tamamlayan kişiden başka uzaktan çalışan birinin varlığıdır. Buna göre katılımcıların \%32.3'ü evinde uzaktan çalışan başka bir kişi "olduğu", \%67.7'lik bir kitle ise evde kendilerinden başka uzaktan çalışan biri olmadığı yanıtını vermiştir. Bu durum her üç kişiden birinin evinde uzaktan çalışan başka bir birey olduğunu ve uzaktan çalışmanın birlikte deneyimlenen, birlikte öğrenilen bir süreç olduğunu gösterebilir.

Katılımcılardan uzaktan çalışma için evdeki imkanları "yeterli" bulanların oranı \%85.1 olarak raporlanırken, katılımcıların \%14.9'u evdeki imkanları "yetersiz" olarak değerlendirmektedir. Bu sonuç, bireylerin evde uzaktan çalışma için fiziksel imkanlarının büyük ölçüde karşılandığını ve devam eden süreçte uzaktan çalışma için yeni iyileştirmelere ihtiyaç duyulmadığını göstermektedir.

Katılımcıların daha önceki uzaktan çalışma tecrübeleri incelendiğinde, \%68.9'unun daha önceden "uzaktan çalışmayı deneyimlemediği", \%31.1'inin ise daha önceden "uzaktan çalışma tecrübesinin olduğu" belirlenmiştir. Bu sonuç, neredeyse üçte bir oranında katılımcının uzaktan çalışma geçmişi olduğunu göstermektedir. Bir yanıyla bu sonuç geleceğin iş biçimi olarak görülen uzaktan çalışmanın halihazırda yaygınlaşmaya başladığını göstermektedir. 
Diğer yanıyla ise katılımcıların daha büyük bir çoğunluğu için yeni olan bu çalışma biçiminin gelecekte yeni sorunları beraberinde getireceğini göstermektedir.

\subsection{Uzaktan Çalışma ile Demografik ve Sosyal Değişkenlerin İlişkisi}

Analizlerin bu bölümünde uzaktan çalışma tutumunda fark yaratan demografik, sosyal ve uzaktan çalışma özelliklerine ilişkin değerlendirmelere yer verilmiştir. Tablo 1, uzaktan çalışma tutumunun sektöre göre farklılaşmasına ilişkin sonuçları göstermektedir.

Tablo 1: Uzaktan Çalışma Tutumunun Sektöre Göre Farklılaşması

\begin{tabular}{lcccc}
\hline \multicolumn{1}{c}{ Ölçek } & Sektör & Ortalama \pm SS & Test & p \\
\hline Olumlu tutum & Özel & $3,16 \pm 1,20$ & M-W U: 20033 & 0,453 \\
Kamu & $3,06 \pm 1,25$ & & 0,852 \\
Beceri geliştirme & Özel & $3,24 \pm 1,14$ & M-W U: 20709 & 0,357 \\
Olumsuz tutuma direnç & Kamu & $3,23 \pm 1,13$ & & \\
& Özel & $3,33 \pm 1,05$ & M-W U: 19827 & 0,149 \\
Kurumsal destek & Kamu & $3,39 \pm 1,18$ & & M-W U: 19208 \\
\multirow{2}{*}{ Uzaktan çalışma tutumu } & Özel & $3,43 \pm 1,23$ & & 0,764 \\
& Kamu & $3,29 \pm 1,17$ & M-W U: 20571 & \\
\hline
\end{tabular}

Uzaktan çalışma tutumuna ilişkin ilk farklılık sektör üzerinden incelenmiştir. Buna göre özel sektör çalışanları ile kamu sektörü çalışanlarının olumlu tutum, beceri geliştirme, olumsuz tutuma direnç, kurumsal destek ve uzaktan çalışma tutumu seviyeleri arasında istatistiki olarak anlamlı bir farklılık olmadığı tespit edilmiştir $(p>0,05)$. Diğer bir ifadeyle farklı sektör çalışanlarının uzaktan çalışmaya ilişkin tutumları ve alt boyutları bakımından farklılaşmadığını söylemek yerinde olacaktır. Bu durum uzaktan çalışma tutumunda özel-kamu ayrımı olmadığını göstermektedir.

Tablo 2: Uzaktan Çalışma Tutumunun Cinsiyete Göre Farklılaşması

\begin{tabular}{|c|c|c|c|c|}
\hline Ölçek & Cinsiyet & Ortalama \pm SS & Test & $\mathbf{p}$ \\
\hline \multirow[t]{2}{*}{ Olumlu tutum } & Kadın & $3,22 \pm 1,22$ & M-W U: 18882 & 0,057 \\
\hline & Erkek & $2,98 \pm 1,21$ & & \\
\hline \multirow[t]{2}{*}{ Beceri geliştirme } & Kadın & $3,29 \pm 1,12$ & M-W U: 19818 & 0,261 \\
\hline & Erkek & $3,16 \pm 1,15$ & & \\
\hline \multirow[t]{2}{*}{ Olumsuz tutuma direnç } & Kadın & $3,35 \pm 1,11$ & M-W U: 21157 & 0,987 \\
\hline & Erkek & $3,36 \pm 1,10$ & & \\
\hline \multirow[t]{2}{*}{ Kurumsal destek } & Kadın & $3,41 \pm 1,18$ & M-W U: 20407 & 0,523 \\
\hline & Erkek & $3,31 \pm 1,24$ & & \\
\hline \multirow[t]{2}{*}{ Uzaktan çalışma tutumu } & Kadın & $3,32 \pm, 84$ & M-W U: 19480 & 0,161 \\
\hline & Erkek & $3,20 \pm, 86$ & & \\
\hline
\end{tabular}

Tablo 2, uzaktan çalışma tutumunun cinsiyete göre farklılaşmasına ilişkin sonuçları göstermektedir. Sonuçlar sektör için elde edilen sonucun bir benzerini göstermektedir. Buna göre, kadın ve erkeklerin olumlu tutum, beceri geliştirme, olumsuz tutuma direnç, kurumsal destek ve uzaktan çalışma tutumu seviyeleri arasında istatistiki olarak anlamlı bir farklılık yoktur ( $p>0,05)$. Diğer bir ifadeyle cinsiyet uzaktan çalışma tutumu ve alt boyutları bakımından fark yaratmamaktadır. 
Tablo 3: Uzaktan Çalışma Tutumunun Çocuk Sahibi Olma Durumuna Göre Farklılaşması

\begin{tabular}{lcccc}
\hline \multicolumn{1}{c}{ Ölçek } & Medeni Durum & Ortalama \pm SS & Test & p \\
\hline Olumlu tutum & Bekar & $3,14 \pm 1,22$ & M-W U: 20983 & 0,663 \\
Beceri geliştirme & Evli & $3,09 \pm 1,22$ & & 0,278 \\
& Bekar & $3,30 \pm 1,13$ & M-W U: 20192 & 0,759 \\
Olumsuz tutuma direnç & Evli & $3,17 \pm 1,14$ & & \\
& Bekar & $3,38 \pm 1,10$ & M-W U: 21139 & 0,611 \\
Kurumsal destek & Evli & $3,34 \pm 1,11$ & & M-W U: 20895 \\
Uzaktan çalışma tutumu & Bekar & $3,39 \pm 1,22$ & & 0,564 \\
& Evli & $3,35 \pm 1,19$ & M-W U: 20809 & \\
\hline
\end{tabular}

Tablo 3, uzaktan çalışma tutumunun medeni duruma göre farklılaşmasına ilişkin sonuçları göstermektedir. Sektör ve cinsiyet için elde edilen bulgu, burada da tekrarlamıştır. Buna göre, bekar ve evli katılımcıların olumlu tutum, beceri geliştirme, olumsuz tutuma direnç, kurumsal destek ve uzaktan çalışma tutumu seviyeleri arasında istatistiki olarak anlamlı bir farklılık yoktur $(p>0,05)$. Diğer bir ifadeyle bireylerin medeni durumları uzaktan çalışmaya ilişkin tutumlarını etkilemesi bakımından anlamlı bir değişken değildir.

Tablo 4: Uzaktan Çalışma Tutumunun Medeni Duruma Göre Farklılaşması

\begin{tabular}{lcccc}
\hline \multicolumn{1}{c}{ Ölçek } & Çocuk Sahibi Olma & Ortalama \pm SS & Test & p \\
\hline Olumlu tutum & Var & $2,93 \pm 1,32$ & M-W U: 16666 & 0,055 \\
Beceri geliştirme & Yok & $3,21 \pm 1,16$ & & 0,305 \\
& Var & $3,13 \pm 1,21$ & M-W U: 18068 & 0,434 \\
Olumsuz tutuma direnç & Yok & $3,28 \pm 1,09$ & & 0,808 \\
Kurumsal destek & Var & $3,28 \pm 1,16$ & M-W U: 18349 & \multirow{2}{*}{0,078} \\
\multirow{3}{*}{ Uzaktan çalışma tutumu } & Yok & $3,39 \pm 1,07$ & M-W U: 18971 & \\
& Var & $3,37 \pm 1,26$ & M-W U: 17212 & \\
\hline
\end{tabular}

Tablo 4, uzaktan çalışma tutumunun çocuk sahibi olma duruma göre farklılaşmasına ilişkin sonuçları göstermektedir. Sektör, cinsiyet ve medeni durum için elde edilen bulgu, burada da tekrarlamıştır. Buna göre, çocuk sahibi olan ve olmayan katılımcıların olumlu tutum, beceri geliştirme, olumsuz tutuma direnç, kurumsal destek ve uzaktan çalışma tutumu seviyeleri arasında istatistiki olarak anlamlı bir farklılık yoktur $(p>0,05)$. Diğer bir ifadeyle bireylerin çocuk sahibi olma durumları uzaktan çalışmaya ilişkin tutumlarını etkilemesi bakımından anlamlı bir değişken değildir. 
Tablo 5: Uzaktan Çalışma Tutumunun Pozisyona Göre Farklılaşması

\begin{tabular}{|c|c|c|c|c|}
\hline Ölçek & Pozisyon & Ortalama $\pm S S$ & Test & $\mathbf{p}$ \\
\hline \multirow[t]{2}{*}{ Olumlu tutum } & Yönetici & $3,13 \pm 1,23$ & M-W U: 16463 & 0,842 \\
\hline & Çalışan & $3,11 \pm 1,22$ & & \\
\hline \multirow[t]{2}{*}{ Beceri geliştirme } & Yönetici & $3,27 \pm 1,15$ & M-W U: 16302 & 0,727 \\
\hline & Çalışan & $3,22 \pm 1,13$ & & \\
\hline \multirow[t]{2}{*}{ Olumsuz tutuma direnç } & Yönetici & $3,36 \pm 1,13$ & M-W U: 16675 & 0,999 \\
\hline & Çalışan & $3,35 \pm 1,10$ & & \\
\hline \multirow[t]{2}{*}{ Kurumsal destek } & Yönetici & $3,25 \pm 1,28$ & M-W U: 15667 & 0,345 \\
\hline & Çalışan & $3,41 \pm 1,18$ & & \\
\hline \multirow[t]{2}{*}{ Uzaktan çalışma tutumu } & Yönetici & $3,25 \pm, 83$ & M-W U: 16454 & 0,836 \\
\hline & Çalışan & $3,28 \pm, 86$ & & \\
\hline
\end{tabular}

Tablo 5, uzaktan çalışma tutumunun pozisyona göre farklılaşmasına ilişkin sonuçları göstermektedir. Sektör, cinsiyet, medeni durum ve çocuk sahibi olma durumu için elde edilen bulgu, burada da tekrarlamıştır. Buna göre, yöneticiler ile çalışanların olumlu tutum, beceri geliştirme, olumsuz tutuma direnç, kurumsal destek ve uzaktan çalışmaya karşı tutum seviyeleri arasında anlamlı bir farklılık olmadığı görülmüştür $(p>0,05)$. Diğer bir ifadeyle farklı pozisyonda çalışanların uzaktan çalışmaya ilişkin tutumları ve alt boyutları bakımından farklılaşmadığını söylemek yerinde olacaktır.

Tablo 6: Uzaktan Çalışma Tutumunun Eğitim Durumuna Göre Farklılaşması

\begin{tabular}{|c|c|c|c|c|}
\hline Ölçek & Eğitim Durumu & Ortalama \pm SS & Test & $\mathbf{p}$ \\
\hline \multirow[t]{2}{*}{ Olumlu tutum } & Lisans & $2,98 \pm 1,21$ & M-W U: 18649 & $0,019 *$ \\
\hline & Lisansüstü & $3,26 \pm 1,22$ & & \\
\hline \multirow[t]{2}{*}{ Beceri geliştirme } & Lisans & $3,11 \pm 1,15$ & M-W U: 18723 & $0,022 *$ \\
\hline & Lisansüstü & $3,37 \pm 1,10$ & & \\
\hline \multirow[t]{2}{*}{ Olumsuz tutuma direnç } & Lisans & $3,29 \pm 1,09$ & M-W U: 19917 & $0,039 *$ \\
\hline & Lisansüstü & $3,43 \pm 1,12$ & & \\
\hline \multirow[t]{2}{*}{ Kurumsal destek } & Lisans & $3,20 \pm 1,28$ & M-W U: 18305 & $0,008^{*}$ \\
\hline & Lisansüstü & $3,55 \pm 1,10$ & & \\
\hline \multirow[t]{2}{*}{ Uzaktan çalışma tutumu } & Lisans & $3,15 \pm, 83$ & M-W U: 17735 & $0,002^{*}$ \\
\hline & Lisansüstü & $3,40 \pm, 85$ & & \\
\hline
\end{tabular}

Tablo 6, uzaktan çalışma tutumunun eğitim durumuna göre farklılaşmasına ilişkin sonuçları göstermektedir. Eğitim durumuna göre katılımcılar incelendiğinde; lisansüstü düzeyde eğitim almış olanların olumlu tutum, beceri geliştirme, olumsuz tutuma direnç, kurumsal destek ve uzaktan çalışma tutumu seviyeleri bakımından lisans düzeyinde eğitim almışlardan daha yüksek ortalamalara sahip olduğu görülmüştür ve bu fark istatistiki olarak da anlamlıdır $(p<0,05)$. Bu durum, şimdiye dek araştırılan sorular bağlamında ilk farkın ortaya çıktığı noktadır. Buna göre, eğitim düzeyi, uzaktan çalışma tutumunu ve alt faktörlerini etkilemektedir. 
Tablo 7: Uzaktan Çalışma Tutumunun Uzaktan Çalışma Durumuna Göre Farklılaşması

\begin{tabular}{lcccc}
\hline \multicolumn{1}{c}{ Ölçek } & Uzaktan Çalışma Durumu & Ortalama & Test & p \\
\hline Olumlu tutum & Zorunluluk & $3,13 \pm 1,22$ & M-W U: 18703 & 0,814 \\
Beceri geliştirme & Kendi tercihi & $3,10 \pm 1,22$ & & 0,235 \\
& Zorunluluk & $3,28 \pm 1,14$ & M-W U: 17615 & 0,080 \\
Olumsuz tutuma direnç & Kendi tercihi & $3,13 \pm 1,13$ & & \\
& Zorunluluk & $3,25 \pm 1,14$ & M-W U: 15929 & $0,010^{*}$ \\
Kurumsal destek & Kendi tercihi & $3,57 \pm 1,01$ & & \\
& Zorunluluk & $3,48 \pm 1,16$ & M-W U: 16033 & 0,609 \\
Uzaktan çalışma tutumu & Kendi tercihi & $3,15 \pm 1,28$ & \multirow{2}{*}{ M-W U: 18385} & \\
& Zorunluluk & $3,28 \pm, 86$ & & \\
\hline
\end{tabular}

Tablo 7, uzaktan çalışma tutumunun uzaktan çalışma durumuna göre farklılaşmasına ilişkin sonuçları göstermektedir. Buna göre uzaktan çalışmayı "zorunluluk" olarak gerçekleştirilenler ile "kendi tercihi" olarak görenlerin olumlu tutum, beceri geliştirme, olumsuz tutuma direnç ve uzaktan çalışma tutumu seviyeleri arasında anlamlı bir farklılık olmadığı görülmüştür $(p>0,05)$. Diğer yandan, uzaktan çalışmayı zorunluluk olarak gerçekleştirenlerin "kurumsal destek" algısının, uzaktan çalışmayı kendi tercihi olarak gerçekleştirenlerin algısından daha yüksek olduğu ve bu farkın istatistiki olarak anlamlı olduğu tespit edilmiştir $(p<0,05)$. Bu durum örgütlerin uzaktan çalışmayı zorunlu tuttuğu durumlarda uzaktan çalışma ve yansımalarına ilişkin destek sağladığı sonucuna işaret etmektedir.

Tablo 8: Uzaktan Çalışma Tutumunun Uzaktan Çalışma Sıklığına Göre Farklılaşması

\begin{tabular}{|c|c|c|c|c|}
\hline Ölçek & Uzaktan Çalışma Sıklığı & Ortalama & Test & $\mathbf{p}$ \\
\hline \multirow[t]{3}{*}{ Olumlu tutum } & Sürekli & $3,33 \pm 1,15$ & Ki-kare: 8,606 & $0,014^{*}$ \\
\hline & Haftanın belirli günleri & $2,95 \pm 1,29$ & & \\
\hline & Ayın belirli günleri & $3,00 \pm 1,14$ & & \\
\hline \multirow[t]{3}{*}{ Beceri geliştirme } & Sürekli & $3,26 \pm 1,12$ & Ki-kare: 0,441 & 0,802 \\
\hline & Haftanın belirli günleri & $3,18 \pm 1,16$ & & \\
\hline & Ayın belirli günleri & $3,29 \pm 1,11$ & & \\
\hline \multirow[t]{3}{*}{ Olumsuz tutuma direnç } & Sürekli & $3,36 \pm 1,12$ & Ki-kare: 0,272 & 0,873 \\
\hline & Haftanın belirli günleri & $3,38 \pm 1,11$ & & \\
\hline & Ayın belirli günleri & $3,31 \pm 1,06$ & & \\
\hline \multirow[t]{3}{*}{ Kurumsal destek } & Sürekli & $3,60 \pm 1,20$ & Ki-kare: 13,129 & $0,001^{*}$ \\
\hline & Haftanın belirli günleri & $3,17 \pm 1,21$ & & \\
\hline & Ayın belirli günleri & $3,32 \pm 1,16$ & & \\
\hline \multirow[t]{3}{*}{ Uzaktan çalışma tutumu } & Sürekli & $3,39 \pm, 86$ & Ki-kare: 5,748 & $0,046^{*}$ \\
\hline & Haftanın belirli günleri & $3,17 \pm, 87$ & & \\
\hline & Ayın belirli günleri & $3,23 \pm, 75$ & & \\
\hline
\end{tabular}

Tablo 8, uzaktan çalışma tutumunun uzaktan çalışma sıklığına göre farklılaşmasına ilişkin sonuçları göstermektedir. Buna göre uzaktan çalışma sıklığı beceri geliştirme ve olumsuz tutuma direnç üzerinde fark yaratmamaktadır ( $p>0,05)$. Diğer yandan ise uzaktan çalışma sıklığı, olumlu tutum, kurumsal destek ve uzaktan çalışma tutumu seviyesinde fark yaratıcı bir etkiye sahiptir $(p<0,05)$. Buna göre gerçekleştirilen test sonucunda (M-W U) "sürekli" uzaktan çalışanların uzaktan çalışmaya ilişkin olumlu tutumları "haftanın belirli günlerinde" uzaktan çalışanlara kıyasla daha yüksektir $(p<0,05)$. Benzer durum kurumsal destek ve uzaktan çalışma tutumu için de geçerlidir $(p<0,05)$. Bu sonuç, sürekli uzaktan çalışanların uzaktan çalışmaya daha olumlu baktıklarını, kurumsal desteği daha çok hissettiklerini ve uzaktan çalışmanın geneline ilişkin tutum seviyelerinin daha yüksek olduğunu göstermektedir. Diğer bir ifade ile çalışanların uzaktan çalışmayı sürekli hale getirmesi, tutumları iyileştirmede önemli bir etken olarak görülmektedir. 
Tablo 9: Uzaktan Çalışma Tutumunun İş Yükü Durumuna Göre Farklılaşması

\begin{tabular}{|c|c|c|c|c|}
\hline Ölçek & İş Yükü Durumu & Ortalama & Test & $\mathbf{p}$ \\
\hline \multirow[t]{3}{*}{ Olumlu tutum } & Arttı & $2,87 \pm 1,20$ & Ki-kare: 12,285 & $0,002^{*}$ \\
\hline & Aynı kaldı & $3,29 \pm 1,21$ & & \\
\hline & Azaldı & $3,32 \pm 1,22$ & & \\
\hline \multirow[t]{3}{*}{ Beceri geliştirme } & Arttı & $3,02 \pm 1,16$ & Ki-kare: 10,597 & $0,005^{*}$ \\
\hline & Aynı kaldı & $3,40 \pm 1,11$ & & \\
\hline & Azaldı & $3,38 \pm 1,07$ & & \\
\hline \multirow[t]{3}{*}{ Olumsuz tutuma direnç } & Arttı & $2,83 \pm 1,13$ & Ki-kare: 63,926 & $0,000 *$ \\
\hline & Aynı kaldı & $3,77 \pm, 90$ & & \\
\hline & Azaldı & $3,69 \pm, 93$ & & \\
\hline \multirow[t]{3}{*}{ Kurumsal destek } & Arttı & $3,35 \pm 1,22$ & Ki-kare: 1,577 & 0,455 \\
\hline & Aynı kaldı & $3,44 \pm 1,22$ & & \\
\hline & Azaldı & $3,27 \pm 1,17$ & & \\
\hline \multirow[t]{3}{*}{ Uzaktan çalışma tutumu } & Arttı & $3,02 \pm, 80$ & Ki-kare: 25,359 & $0,000 *$ \\
\hline & Aynı kaldı & $3,48 \pm, 84$ & & \\
\hline & Azaldı & $3,41 \pm, 84$ & & \\
\hline
\end{tabular}

Tablo 9, uzaktan çalışma tutumunun iş yükü durumuna göre farklılaşmasına ilişkin sonuçları göstermektedir. Buna göre uzaktan çalışma sonrasında iş yükünün değişmesi, olumlu tutum, beceri geliştirme, olumsuz tutuma direnç ve uzaktan çalışma tutumu seviyelerinde fark yaratmakta $(p<0,05)$, kurumsal destek için ise fark yaratmamaktadır $(p>0,05)$. Gerçekleştirilen test sonrasında (M-W U); olumlu tutumdaki gelişme iş yükünün "azaldığını" belirtenler ile "arttığın”" belirtenler arasındaki farktan kaynaklanmaktadır $(p<0,05)$. İ̧ yükünün azaldığını belirtenlerin uzaktan çalışmaya olumlu tutum seviyeleri daha yüksektir. Beceri geliştirme açısından durum incelendiğinde farkın iş yükünü "aynı" ve "azalmış" bulanlar ile "arttığını" dile getirenler arasındaki farktan kaynaklandığı görülmektedir. Buna göre iş yükü aynı kalan ya da azalan çalışanların beceri geliştirme seviyeleri iş yükü artanlardan daha yüksektir. Olumsuz tutuma direnç için de benzer bir durum söz konusudur. Buradaki farkın iş yükünü "aynı" ve "azalmış" bulanlar ile "arttığını" dile getirenler arasındaki farktan kaynaklandığı görülmektedir. Son olarak genel bağlamda uzaktan çalışma tutumu incelendiğinde; benzer şekilde buradaki farkın iş yükünü "aynı" ve "azalmış" bulanlar ile "arttığını" dile getirenler arasındaki farktan kaynaklandığı görülmektedir. Diğer bir ifade ile iş yükü arttıkça uzaktan çalışma tutumu değerlendirmesi düşmektedir. Bu bağlamda örgütlerin iş yükünü kontrol etmeden uzaktan çalışmaya geçmesinin, bireylerin uzaktan çalışmaya karşı bakışlarını olumsuz etkileyebildiği düşünülebilir.

Tablo 10: Uzaktan Çalışma Tutumunun Evde Başka Çalışan Olma Durumuna Göre Farklılaşması

\begin{tabular}{|c|c|c|c|c|}
\hline Ölçek & $\begin{array}{c}\text { Evde Başka Uzaktan } \\
\text { Çalışan Olması }\end{array}$ & Ortalama & Test & $\mathbf{p}$ \\
\hline \multirow[t]{2}{*}{ Olumlu tutum } & Evet & $3,33 \pm 1,18$ & M-W U: 16005 & $0,013 *$ \\
\hline & Hayır & $3,01 \pm 1,23$ & & \\
\hline \multirow[t]{2}{*}{ Beceri geliştirme } & Evet & $3,34 \pm 1,02$ & M-W U: 17576 & 0,272 \\
\hline & Hayır & $3,18 \pm 1,19$ & & \\
\hline \multirow[t]{2}{*}{ Olumsuz tutuma direnç } & Evet & $3,48 \pm 1,04$ & M-W U: 17065 & 0,122 \\
\hline & Hayır & $3,30 \pm 1,13$ & & \\
\hline \multirow[t]{2}{*}{ Kurumsal destek } & Evet & $3,39 \pm 1,17$ & M-W U: 18688 & 0,903 \\
\hline & Hayır & $3,36 \pm 1,22$ & & \\
\hline \multirow[t]{2}{*}{ Uzaktan çalışma tutumu } & Evet & $3,39 \pm, 82$ & M-W U: 16576 & $0,049 *$ \\
\hline & Hayır & $3,21 \pm, 86$ & & \\
\hline
\end{tabular}


Tablo 10, uzaktan çalışma tutumunun evde başka uzaktan çalışan olma durumuna göre farklılaşmasına ilişkin sonuçları göstermektedir. Buna göre evde başka uzaktan çalışan olması beceri geliştirme, olumsuz tutuma direnç ve kurumsal destek açısından fark yaratmazken $(p>0,05)$; olumlu tutum ve uzaktan çalışma tutumu seviyesinde anlamlı bir fark yaratmaktadır $(p<0,05)$. Evde başka bir çalışanın olması bir yandan olumlu tutumu pekiştirirken diğer yandan da genel uzaktan çalışma tutumunu iyileştirmektedir. Bu durum, uzaktan çalışmanın birlikte öğrenilen bir çalışma biçimi olabilmesinin önünü açmaktadır. Diğer bir ifadeyle geleneksel çalışma biçimindeki sosyal kodlar, bu çalışma biçimiyle birlikte yeniden yazılabilir niteliktedir ki bu durum iş-yaşam dengesi ve iş-aile dengesi gibi yansımaları iyileştirebilme imkanını birlikte getirmektedir.

Tablo 11: Uzaktan Çalışma Tutumunun Uzaktan Çalışma İmkanlarının Yeterliliğine Göre Farklılaşması

\begin{tabular}{|c|c|c|c|c|}
\hline Ölçek & $\begin{array}{c}\text { Uzaktan Çalışma } \\
\text { İmkanlarının Yeterliği }\end{array}$ & Ortalama & Test & $p$ \\
\hline \multirow[t]{2}{*}{ Olumlu tutum } & Evet & $3,23 \pm 1,23$ & M-W U: 6886 & $0,000^{*}$ \\
\hline & Hayır & $2,45 \pm, 95$ & & \\
\hline \multirow[t]{2}{*}{ Beceri geliştirme } & Evet & $3,34 \pm 1,14$ & M-W U: 6868 & $0,000 *$ \\
\hline & Hayır & $2,63 \pm, 93$ & & \\
\hline \multirow[t]{2}{*}{ Olumsuz tutuma direnç } & Evet & $3,46 \pm 1,07$ & M-W U: 7063 & $0,000 *$ \\
\hline & Hayır & $2,78 \pm 1,10$ & & \\
\hline \multirow[t]{2}{*}{ Kurumsal destek } & Evet & $3,42 \pm 1,22$ & M-W U: 8473 & $0,004 *$ \\
\hline & Hayır & $3,06 \pm 1,08$ & & \\
\hline \multirow[t]{2}{*}{ Uzaktan çalışma tutumu } & Evet & $3,36 \pm, 84$ & M-W U: 6225 & $0,000 *$ \\
\hline & Hayır & $2,73 \pm, 69$ & & \\
\hline
\end{tabular}

Tablo 11, uzaktan çalışma tutumunun uzaktan çalışma imkanlarının yeterliğine göre farklılaşmasına ilişkin sonuçları göstermektedir. Buna göre uzaktan çalışma konusunda evdeki imkanların yeterliği; olumlu tutum, beceri geliştirme, olumsuz tutuma direnç, kurumsal destek ve uzaktan çalışma tutumu seviyesinde anlamlı bir fark yaratmaktadır $(p<0,05)$. Evdeki uzaktan çalışma imkanlarının yeterliği olumlu tutumu, beceri geliştirmeyi, olumsuz tutuma direnci, kurumsal destek algısını ve genel uzaktan çalışma tutumunu iyileştirmektedir. Esasen bu durum önemli bir belirteç olarak tespit edilmiştir. Uzaktan çalışmanın geleceğin çalışma modeli olduğu düşünüldüğünde fiziki şartların iyileştirilmesinin yeni çalışma modeline yaklaşımları da iyileştirebileceği unutulmamalıdır.

Tablo 12: Uzaktan Çalışma Tutumunun Önceden Uzaktan Çalışma Tecrübesine Göre Farklılaşması

\begin{tabular}{|c|c|c|c|c|}
\hline Ölçek & $\begin{array}{l}\text { Önceden Uzaktan } \\
\text { Çalışma Tecrübesi }\end{array}$ & Ortalama & Test & $\mathbf{p}$ \\
\hline \multirow[t]{2}{*}{ Olumlu tutum } & Evet & $3,34 \pm 1,20$ & M-W U: 15552 & $0,010^{*}$ \\
\hline & Hayır & $3,02 \pm 1,22$ & & \\
\hline \multirow[t]{2}{*}{ Beceri geliştirme } & Evet & $3,26 \pm 1,14$ & M-W U: 18247 & 0,860 \\
\hline & Hayır & $3,22 \pm 1,14$ & & \\
\hline \multirow[t]{2}{*}{ Olumsuz tutuma direnç } & Evet & $3,40 \pm 1,06$ & M-W U: 17829 & 0,584 \\
\hline & Hayır & $3,34 \pm 1,12$ & & \\
\hline \multirow[t]{2}{*}{ Kurumsal destek } & Evet & $3,60 \pm 1,16$ & M-W U: 15422 & $0,007^{*}$ \\
\hline & Hayır & $3,26 \pm 1,21$ & & \\
\hline \multirow[t]{2}{*}{ Uzaktan çalışma tutumu } & Evet & $3,40 \pm, 81$ & M-W U: 15905 & $0,025^{*}$ \\
\hline & Hayır & $3,21 \pm, 86$ & & \\
\hline
\end{tabular}


Tablo 12, uzaktan çalışma tutumunun önceden uzaktan çalışma tecrübesine göre farklılaşmasına ilişkin sonuçları göstermektedir. Buna göre daha önceden uzaktan çalışma tecrübesinin olması beceri geliştirme ve olumsuz tutuma direnç konusunda fark yaratmazken $(p>0,05)$; olumlu tutum, kurumsal destek ve uzaktan çalışma tutumu konusunda anlamlı bir fark yaratmaktadır $(p<0,05)$. Daha önceden uzaktan çalışmayı deneyimleyenlerin uzaktan çalışmaya daha olumlu baktıkları, kurumsal destek seviyelerinin daha yüksek olduğu ve genel manada uzaktan çalışmaya karşı daha pozitif değerlendirdikleri görülmüştür. Bu durum, uzaktan çalışma deneyimi sonrasında bireylerin uzaktan çalışmaya karşı bakışlarının olumlu hale geldiğinin bir göstergesi olarak okunabilir. 
Eskişehir Osmangazi Üniversitesi İktisadi ve İdari Bilimler Fakültesi Dergisi

Tablo 13: Değişkenler Arasındaki Korelasyonlar

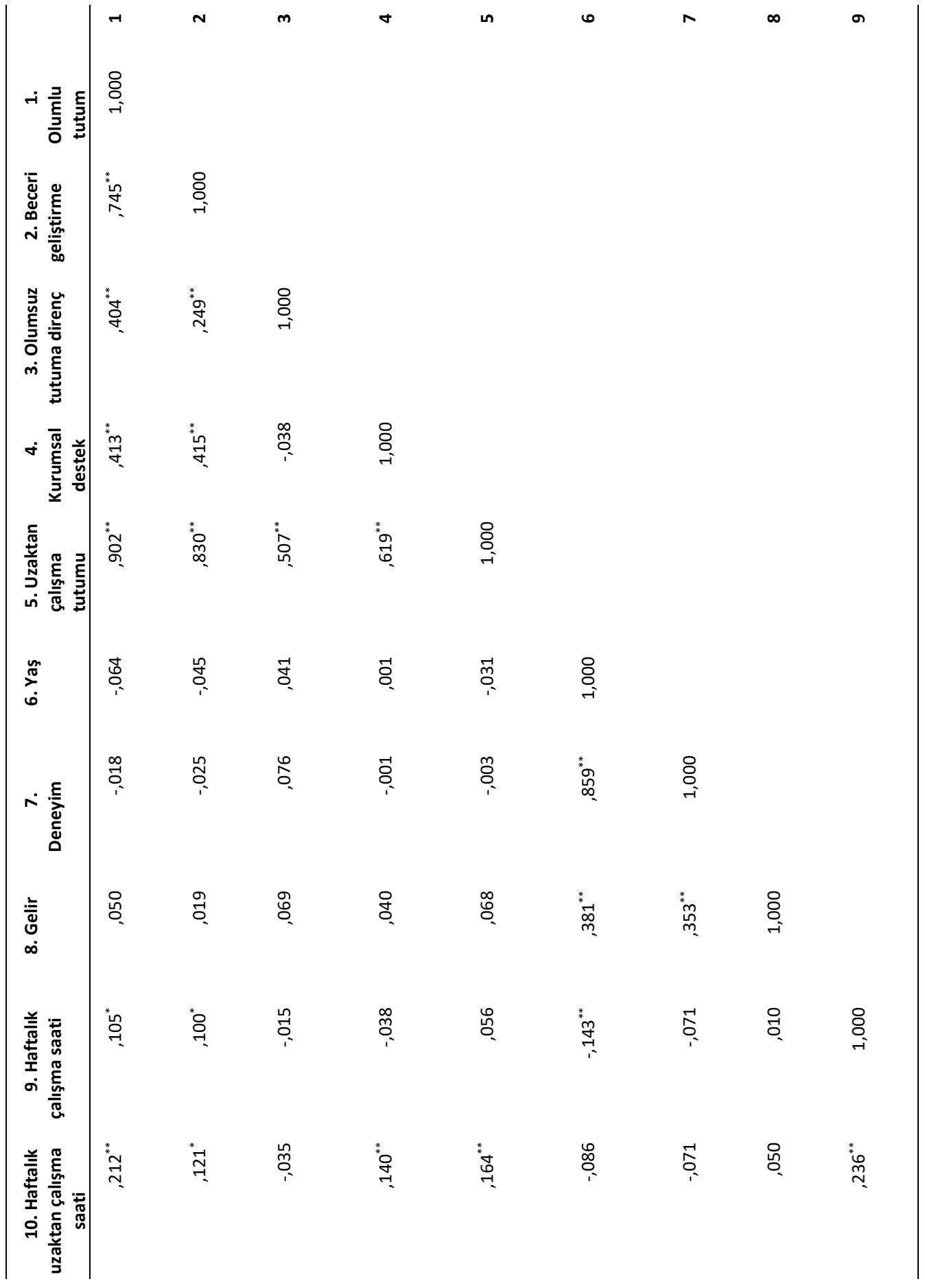


Tablo 13, değişkenler arasındaki korelasyonları göstermektedir. Burada bir fark testi yerine korelasyon testi gerçekleştirilmiştir. Bunun nedeni korelasyona konu olan değişkenlerin "sürekli yapıda" değişken olmalarıdır. Sosyo-demografik değişkenler temelinde durum incelendiğinde; yaş ile olumlu tutum, beceri geliştirme, olumsuz tutuma direnç, kurumsal destek ve uzaktan çalışma tutumu arasında anlamlı bir ilişkinin olmadığı görülmüştür $(p>0,05)$. Aynı durum deneyim ve gelir için de geçerlidir $(p<0,05)$. Buna göre uzaktan çalışanların yaşları, deneyim süreleri ve gelir düzeyleri uzaktan çalışma ve alt boyutlarını etkilememektedir. Bu açıdan uzaktan çalışmanın her yaş, deneyim ve gelir grubu için benzer sonuçlar türettiğini söylemek yerinde olabilir. Diğer yandan; haftalık çalışma saati ile uzaktan çalışma ve alt boyutlarının ilişkisi incelendiğinde; yalnızca beceri geliştirme boyutunu düşük düzeyde, aynı yönde ve anlamlı şekilde etkilediği görülmüştür ( $r: 0,10 ; p<0,05)$. Buna göre haftalık çalışma saatinde meydana gelen bir artış, bireylerin beceri geliştirme kapasitelerini düşük düzeyde arttırma yönünde etkilemektedir. Son olarak, haftalık uzaktan çalışma süresi ile olumlu tutum, beceri geliştirme, kurumsal destek ve uzaktan çalışma tutumu arasında düşük düzeyde, aynı yönlü ve anlamlı ilişki vardır $(p<0,05)$. Haftalık uzaktan çalışma süresi ile olumsuz tutuma direnç arasında ise anlamlı bir ilişki yoktur $(p>0,05)$. Buna göre toplam çalışma süresi içerisindeki uzaktan çalışma süresinin artmasının, olumlu tutumu, beceri geliştirme kapasitesini, örgütsel desteği ve genel uzaktan çalışma tutumunu olumlu etkilediğini söylemek mümkündür. Bu açıdan uzaktan çalışma saatlerinin geliştirilmesi, uzaktan çalışmaya ilişkin tutumu iyileştirmektedir.

Şekil 1: Değişkenlerin Çoklu Karşılaştırma Analizi Ile Birlikte Değerlendirilmesi

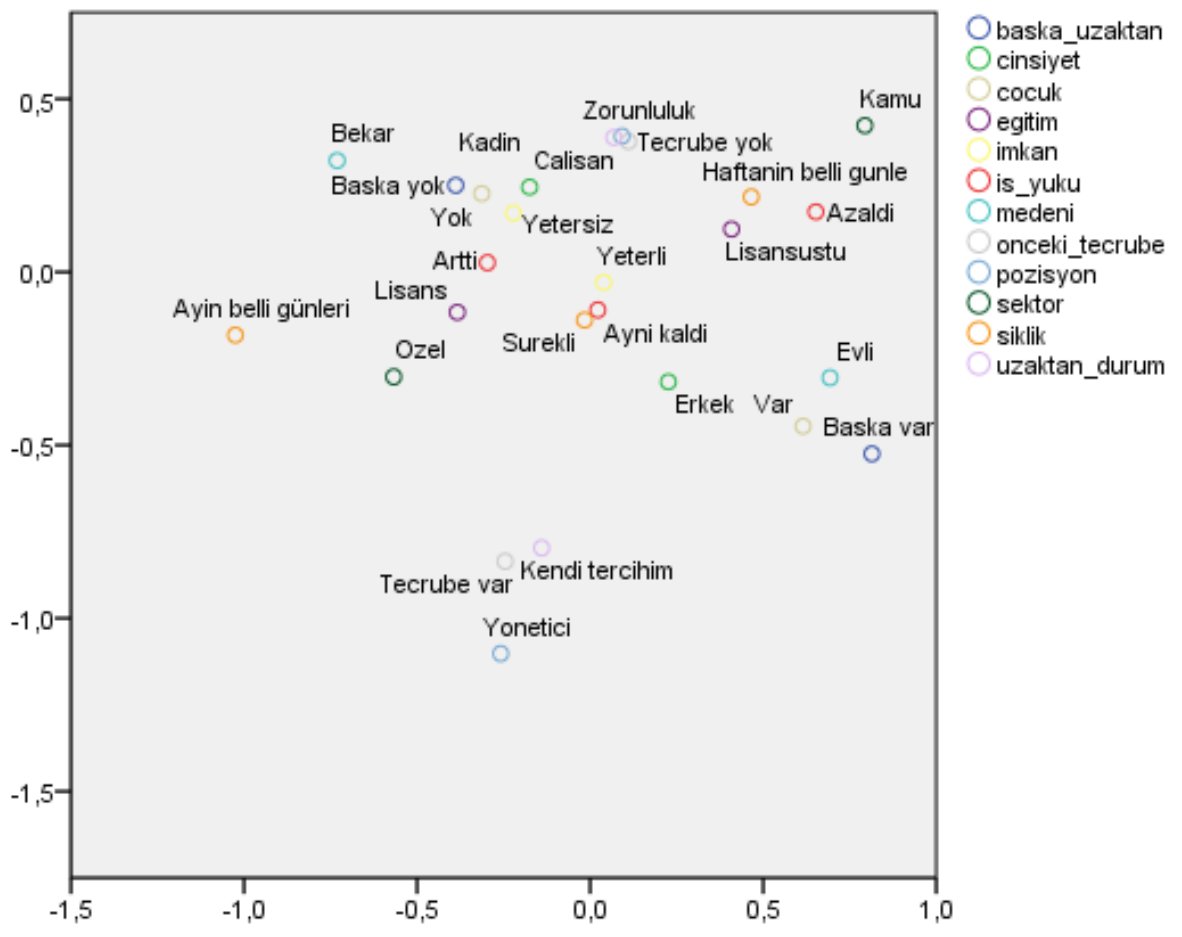


Şekil 1, değişkenlerin çoklu karşılaştırma analizi ile birlikte değerlendirilmesine ilişkin sonuçları göstermektedir. Buna göre, tüm demografik değişkenler bir arada değerlendirildiğinde; kamuda çalışanların haftanın belirli günleri uzaktan çalışan, uzaktan çalışma sonrası iş yükü azalan ve lisansüstü eğitime sahip olanlar olduğu görülmektedir. Öne çıkan bir diğer grup ise yöneticilerin kendi tercihiyle uzaktan çalıştıkları ve daha önceden uzaktan çalışma tecrübelerinin olduğu durumdur. Son olarak özel sektör çalışanlarının uzaktan çalışma sonrasında iş yüklerinin arttığı ve lisans mezunu oldukları ve sürekli uzaktan çalışma biçimine sahip oldukları görülmektedir.

\section{Tartışma}

Gerçekleştirilen analizler sonrasında, uzaktan çalışmaya ilişkin çalışan yaklaşımının, sektör, cinsiyet, medeni durum, çocuk sahibi olma ve iş yerindeki pozisyona göre farklılaşmadığı görülmüştür. Ayrıca mevcut çalışmanın örnekleminde, uzaktan çalışanların yaşları, deneyim süreleri ve gelir düzeylerinin uzaktan çalışma ve alt boyutlarını etkilemediği görülmüştür. Bu bağlamda, temel sosyo-demografik özelliklerin uzaktan çalışma tutumu üzerinde fark yaratıcı etkisinin olmadığını söylemek yerinde olacaktır. Ancak eğitim düzeyinin uzaktan çalışma tutumunu etkilediği görülmüştür. Çalışanın eğitim düzeyinin yükselmesi ile paralel olarak uzaktan çalışmaya olan tutumunun da iyileştiği bulgusu, Lund vd.'nin (2021: 70) ifade ettikleri, yüksek eğitimli kesimlerin gelecekte teknoloji/dijital tabanlı ve uzaktan çalışmaya müsait işlerde daha rekabetçi ve avantajlı olabilecekleri savıyla paralellik arz etmektedir. Bu kapsamda, önümüzdeki süreçte özellikle beyaz yaka çalışanların eğitim seviyelerini yükseltmeleri ve dijital dünyayla uyumlu yeni beceriler kazanabilmeleri elzem hale gelmektedir. Öte yandan Bozkurt (2020) tarafından da ifade edildiği gibi, işlerinin niteliği uzaktan çalışmaya uygun olmayan kişiler bu anlamda dezavantajlı bir konuma gerilemektedir.

Çalışmanın bir diğer bulgusu, uzaktan çalışmanın zorunluluk olarak uygulandığı durumlarda çalışanlardaki "kurumsal destek" algısının da yükseldiği bulgusudur. Bu durum, kurumların/şirketlerin uzaktan çalışmayı zorunlu tuttuğu durumlarda uzaktan çalışma ve yansımalarına ilişkin gerekli altyapı ve eğitim desteğini sağlamaya çalıştıkları şeklinde yorumlanabilir. Çalışanların uzaktan çalışma sıklıklarına bakıldığında ise, sürekli ve düzenli bir biçimde uzaktan çalışan kişilerin bu uygulamalara daha olumlu baktıkları ve kurumsal desteği daha fazla hissettikleri ortaya çıkmaktadır. Bu bulgular, uzaktan çalışmanın organizasyonlar tarafından ciddiye alınıp, planlı-programlı, profesyonel biçimde ve sürekli/düzenli olarak uygulandığında çalışanın tutumlarının iyileşmesi sonucunu doğurduğunu ortaya koymaktadır. Prasad vd.'ne (2020: 386-387) göre de organizasyonlar verimliliği arttırmak için hangi tür işlerin uzaktan yapılabileceği ile ilgili planlamalarını önceden yapmalı ve uygulamalara ilişkin politika belgeleri hazırlamalıdır. Ayrıca organizasyonların fiziksel uzaklıktan kaynaklı iletişim problemlerini en aza indirgemek için yenilikçi yollar bulmaları ve çalışanlar arasındaki iletişim kanallarını teknik ve pratik olarak sürekli işler halde tutmaları önem arz etmektedir. Bu bağlamda uzaktan çalışma sırasında çalışanların kendi arasındaki ve yöneticilerle çalışanlar arasındaki iletişimin iyileştirilmesinin gerekliliği, bu amaçla düzenli toplantılarla (resmi ya da sosyal) kurum kültürünün ve paylaşılan ortak değerlerin yaşatılmasının önemi literatürde vurgulanmaktadır (Hancock ve Schaninger, 2020: 6; Phillips, 2020)

Öte yandan, uzaktan çalışmaya geçiş sonrasında iş yükünün arttığını belirten çalışanların uzaktan çalışmaya olan olumlu tutum seviyelerinin düştüğü gözlemlenmiştir. Bu bağlamda kurumların/şirketlerin iş yükünü kontrol etmeden uzaktan çalışmaya geçmesinin, bireylerin uzaktan çalışmaya karşı bakışlarını olumsuz etkileyebildiği söylenebilir. Altı çizilmesi gereken 
nokta, dijital teknolojilerin sayesinde sürekli "ulaşılabilir" halde olan çalışanlarının bu pozisyonlarını kötüye kullanmamanın ve onların özel/aile yaşamları için ayırmaları gereken zaman dilimlerine saygı göstermenin önemidir. Son dönemde yapılan bazı araştırmalar, iş nedeniyle sürekli olarak çevrimiçi bulunma ve akıllı telefon ya da taşınabilir bilgisayarları kontrol etmenin hem çalışan psikolojisine hem de çalışanın aile ilişkilerine zarar verdiğini ortaya koymuştur (Anderson ve Kelliher, 2020; Molino vd., 2020) Wang vd.'ne (2021: 45) göre uzaktan çalışma dönemlerinde artan iş yükü çalışanların iş yaşam dengelerinin kötüleşmesine ve mutluluk seviyelerinin düşmesine neden olmaktadır. Kurumlara/şirketlere düşen bir diğer görev de, gerekli teknik/dijital altyapıyı sağlamanın yanı sıra, çalışanlarının iş yüklerini dengeli düzeyde tutmak ve onların mesai dışı kişisel alanlarına müdahil olmamaktır. Literatürde de daha önce ifade edildiği gibi, iyi uygulanan esnek çalışma modellerinde çalışan sosyal, kültürel ve eğitim faaliyetlerine daha çok zaman ayırarak motivasyonunu yükseltebilir (Çakır, 2001).

Ayrıca, belirli profiller ortaya çıkarmaya yarayan çoklu karşılaştırma analizi sonucu ortaya çıkan en çarpıcı bulgu, özel sektörde sürekli olarak uzaktan çalışan lisans mezunu çalışan grubunun iş yükü artarken; kamu sektöründe haftanın belirli günlerinde (dönüşümlü) uzaktan çalışan lisansüstü mezuniyete sahip grubun iş yükünün azalmasıdır. Bu bulgu çerçevesinde, uzaktan çalışma döneminde çalışanlarının iş yüklerini dengeli tutma konusunda özel sektörün ilave bir hassasiyet göstermesinin yerinde olacağı değerlendirilmektedir. Keser'in (2021) uzaktan çalışma deneyimi ile ilgili araştırmasında da "artan iş yükü ile boğuşmak" çalışanların bu dönemde yaşadıkları belirgin sorunlardan biri olarak öne çıkmaktadır.

Ayrıca araştırmada, evde uzaktan çalışan başka bir kişinin daha bulunmasının olumlu tutumu pekiştirdiği görülmüştür. Söz konusu uygulamalar ilk defa bu kadar yoğun deneyimlendiğinden ve dijital beceri gerektirdiğinden, evde başka bir uzaktan çalışanla yardımlaşmanın ve karşılıklı deneyim aktarımının olumlu tutumu desteklemiş olabileceği düşünülmektedir. Bir diğer bulgu, evdeki uzaktan çalışma imkânlarının yeterliliğinin olumlu tutumu, beceri geliştirmeyi, olumsuz tutuma direnci, kurumsal destek algısını ve genel uzaktan çalışma tutumunu iyileştirdiğidir. Bu bulgu, çalışma ortamındaki taşınabilir bilgisayar, güncel yazııım, mobil telefon, uygun çalışma alanı ve yüksek hızlı internet gibi olanakların sağlıklı biçimde sağlanabilmesinin olumlu tutumu ve dolayısıyla performansı/üretkenliği arttırabileceğini göstermektedir. Son olarak, pandemi öncesinde uzaktan çalışma tecrübesi olan kişilerin uzaktan çalışmaya daha olumlu baktıkları görülmüştür ve bu kişilerin deneyimleri sayesinde oryantasyon aşamasını daha hızlı biçimde aşarak yeni şartlara daha kolay uyum sağladıkları düşünülmektedir. 


\section{Sonuç}

Mevcut araştırma, "Uzaktan çalışmanın sosyal ve demografik değişkenlerle ilişkisi nedir? sorusu üzerine odaklanmaktadır. Araştırmaya, Türkiye'nin farklı şehirlerinde yaşayan, kamu ya da özel sektörde istihdam edilen, pandemi döneminde en az 1 saat uzaktan çalışma deneyimine sahip olan 415 kişi katılmıştır. Araştırma sonuçları, katılımcıların \%67.2'sinin uzaktan çalışmayı bir "zorunluluk" olarak deneyimlediklerini; katılımcıların yaklaşık \%80'inin ya sürekli ya da haftanın belirli günlerinde uzaktan çalışmakta olduğunu; uzaktan çalışma sonrasında çalışanların \%80'inden fazlasının iş yükünün artmış ya da aynı kalmış olduğunu; katılımcıların \%67.7'sinin evde kendinden başka uzaktan çalışan biri olmadığını; katılımcıların \%85.1'inin evde çalışma için gerekli imkanları yeterli gördüğünü ve katılımcıların \%68.9'unun pandemi öncesinde "uzaktan çalışmayı deneyimlemediğini göstermiştir.

Elde edilen tüm veriler birlikte değerlendirildiğinde, uzaktan çalışma organizasyonunun planlı ve düzenli bir biçimde gerçekleştirildiği, gerekli teknik/dijital altyapının sağlandığı, eğitim düzeylerinin yükseltildiği ve çalışanın iş yükünün arttırılmadığı, ailesine ve özel yaşamına zaman ayırmasına özen gösterildiği durumlarda uzaktan çalışmaya karşı gelişen olumlu tutum seviyelerinin yükseldiği görülmüştür. Genel olarak beyaz yakalı çalışanların eğitim seviyeleri yükseldikçe uzaktan çalışmaya karşı daha olumlu bir perspektif geliştirdikleri söylenebilmekle birlikte, organizasyonların da uzaktan çalışma sürecine hazırlıklı olmaları ve değişen şartlara dijitalleşmeyle olduğu kadar çalışanlarına karşı sorumluluklarını yerine getirerek de uyum sağlamalarının öneminin altı çizilmelidir.

Gelecek çalışmalarda, uzaktan çalışma tutumuna ilişkin analizleri kamu-özel sektör ayrımı yaparak ve farklı sektörel alt-kırılımları da dikkate alarak geliştirmek mümkün gözükmektedir. Öte yandan çalışanların uzaktan çalışma dönemindeki deneyimlerini derinlemesine görüşmelerle analiz etmenin ve karşılaştırmalı uluslararası çalışmalar yapmanın da alandaki literatüre önemli katkı yapabileceği düşünülmektedir. 


\section{Kaynakça}

Allen, T. D.; Golden, T. D.; Shockley, K. M. (2015), “How Efective Is Telecommuting? Assessing the Status of Our Scientifc Findings", Psychological Science in the Public Interest, Vol. 16, No. 2, 40-68.

Anderson, D.; Kelliher, C. (2020). "Enforced remote working and the work-life interface during lockdown." Gender in Management: An International Journal, Vol. 35, No. 7-8, 677-683.

Aşkın, K. (2021). "Evde Çalışma Araştırması" https://www.linkedin.com/feed/update/urn:li:ugcPost:6794332066835132416/ (Erişim 11.07.2021).

Beise, C.M.; Carte, T.A.; Vician, C.; Chidambaram, L. (2010), "A case study of project management practices in virtual settings.", ACM SIGMIS Database: Database Adv. Inf. Syst., Vol. 41, No. 4, 75-97.

Bellmann, L.; Hübler, O. (2020), "Working from home, job satisfaction and work-life balance-robust or heterogeneous links?", International Journal of Manpower. Vol. 42, No. 3, 424-441.

Bloom, N.; Liang, J.; Roberts, J.; Ying, Z. J. (2015), “Does Working from Home Work? Evidence from a Chinese Experiment", The Quarterly Journal of Economics, Vol. 130, No. 1, 165-218.

Bozkurt, V. (2020), "Working During a Pandemic: Economic Concerns, Digitalization, and Productivity", The COVID-19 Pandemic and Its Economic, Social, and Political Impacts, 87-106.

Choudhury, P.; Foroughi, C.; Larson, B. (2021), "Work-from-anywhere: The productivity effects of geographic flexibility", Strategic Management Journal, Vol. 42, No. 4, 655-683.

Çakır, Ö. (2001), "Yeni Çalışma Biçimleri ve iş̧e Iilişkin Tutumlar", Iş-Güç, Endüstri ilişkileri ve insan Kaynakları Dergisi, Cilt. 3, Sayı, 1.

Das, M.; Tang, J.; Ringland, K. E.; Piper, A. M. (2021), "Towards Accessible Remote Work: Understanding Work-from-Home Practices of Neurodivergent Professionals", Proceedings of the ACM on Human-Computer Interaction, Vol. 5, 1-30.

Di Martino, V.; Wirth, L. (1990), "Telework: A new way of working and living", International Labour Review, Vol. 129, No. 5, 529-554.

Grant, C. A.; Wallace, L. M.; Spurgeon, P. C. (2013), "An exploration of the psychological factors afecting remote e-worker's job efectiveness, well-being and work-life balance", Employee Relations, Vol. 35, No. 5, 527-546.

Hancock, B.; Schaninger, B. (2020). "HR says talent is crucial for performance-and the pandemic proves it." https://www.idfa.org/wordpress/wp-content/uploads/2020/09/HR-says-talent-is-crucial-forperformance-and-the-pandemic-proves-it-v3.pdf (Erişim 11.07.2021)

Felstead, A.; Henseke, G. (2017), "Assessing the growth of remote working and its consequences for effort, well-being and work-life balance", New Technology, Work and Employment, Vol. 32, No. 3, 195212.

Ferreira, R.; Pereira, R.; Bianchi, I.S.; da Silva, M.M. (2021), "Decision Factors for Remote Work Adoption: Advantages, Disadvantages, Driving Forces and Challenges", J. Open Innov. Technol. Mark. Complex., Vol. 7, No. 70.

Flores, M. F. (2019), "Understanding The Challenges Of Remote Working And It's Impact To Workers", International Journal of Business Marketing and Management (IJBMM), Vol. 4, No. 11, 40-44.

Golden, T. D.; Eddleston, K. A. (2020), "Is there a price telecommuters pay? Examining the relationship between telecommuting and objective career success", Journal of Vocational Behavior, Vol. 116, 87-111.

Hunter, P. (2019), "Remote working in research: An increasing usage of flexible work arrangements can improve productivity and creativity", EMBO reports, Vol. 20, No. 1.

Lund, S.; Madgavkar, A.; Manyika, J.; Smit, S.; Ellingrud, K.; Meaney, M.; Robinson, O. (2021), "The future of work after COVID-19", McKinsey, https://www.mckinsey.com/featured-insights/future-ofwork/the-future-of-work-after-covid-19 (Erişim 10.05.2021). 
Mattarelli, E.; Tagliaventi, M.R. (2010), "Work-Related Identities, Virtual Work Acceptance and the Development of Glocalized Work Practices in Globally Distributed Teams" Ind. Innov, Vol. 17, 415-443.

Mazmanian, M.; Orlikowski, W. J.; Yates, J. (2013), "The autonomy paradox: The implications of mobile email devices for knowledge professionals" Organization science, Vol. 24, No. 5, 1337-1357.

Mihhailova, G. (2009), "Management challenges arising from the use of virtual work", Balt. J. Manag., Vol. 4, 80-93.

Mihhailova, G.; Õun, K.; Türk, K. (2011), "Virtual work usage and challenges in different service sector branches", Balt. J. Manag., Vol. 6, 342-356.

Molino, M.; Ingusci, E.; Signore, F.; Manuti, A.; Giancaspro, M. L.; Russo, V.; Cortese, C. G. (2020). "Wellbeing costs of technology use during Covid-19 remote working: An investigation using the Italian translation of the technostress creators scale". Sustainability, Vol. 12, No. 15, 1-20.

Moss, J. (2018), "Helping remote workers avoid loneliness and burnout", Harvard Business Review on Health, https://hbr.org/2018/11/helping-remote-workers-avoid-loneliness-and-burnout (Erişim 11.05.2021).

Owl Labs. (2021), "The State of Remote Work Report", https://resources.owllabs.com/state-ofremote-work, (Erişim 10.05.2021)

Palumbo, R. (2020), "Let me go to the office! An investigation into the side effects of working from home on work-life balance", International Journal of Public Sector Management, Vol. 33, No. 6-7, 771790.

Phillips S. (2020). "Working through the pandemic: Accelerating the transition to remote working." Business Information Review. Vol. 37, No. 3, 129-134.

Prasad, D. K.; Rao, M.; Vaidya, D. R.; Muralidhar, B. (2020), “Organizational climate, opportunities, challenges and psychological wellbeing of the remote working employees during COVID-19 pandemic: a general linear model approach with reference to information technology industry in hyderabad", International Journal of Advanced Research in Engineering and Technology (IJARET), Vol. 11, No. 4, 372-389.

Putnam, L. L.; Myers, K. K.; Gailliard, B. M. (2014), "Examining the tensions in workplace fexibility and exploring options for new directions", Human Relations, Vol. 67, No. 4, 413-440.

Putra, K. C.; Pratama, T. A.; Linggautama, R. A.; Prasetyaningtyas, S. W. (2020), "The Impact of Flexible Working Hours, Remote Working, and Work Life Balance to Employee Satisfaction in Banking Industry during Covid-19 Pandemic Period", Journal of Business Management Review, Vol. 1, No. 5, 341353.

Rogers, Y. (2020), "Is Remote the New Normal? Reflections on Covid-19, Technology, and Humankind", Interactions, Vol. 27, No. 4, 42-46.

Schall, M. A. (2019), "The relationship between remote work and job satisfaction: The mediating roles of perceived autonomy, work-family conflict, and telecommuting intensity", Master Thesis, https://scholarworks.sjsu.edu/etd_theses/5017/ (Erişim 09.05.2021).

Sivunen, A.; Nurmi, N.; Koroma, J. (2016), "When a one-hour time difference is too much: Temporal boundaries in global virtual work", In Proceedings of the Annual Hawaii International Conference on System Sciences, Koloa, HI, USA, 511-520.

Sullivan C. (2012), "Remote Working and Work-Life Balance", In: Reilly N., Sirgy M., Gorman C. (eds) Work and Quality of Life. International Handbooks of Quality-of-Life. Springer: Dordrecht.

Sundin, K. (2008), "Virtual Teams: Work/Life Challenges-Keeping Remote Employees Engaged", Cornell University Library: Ithaca, NY, USA, 81-98.

Thompson, B.Y. (2018), "The Digital Nomad Lifestyle: (Remote) Work/Leisure Balance, Privilege, and Constructed Community", Int. J. Sociol. Leis., Vol. 2, 27-42. 
Vartiainen, M.; Andriessen, E. (2006), “Mobile virtual work: What have we learned? In Mobile Virtual Work: A New Paradigm?", Springer: Berlin/Heidelberg, Germany, 369-386.

Vartiainen, M. A. (2012), "Facilitating Mobile and Virtual Work", In 21st Century Management: A Reference Handbook; SAGE Publications: Thousand Oaks, CA, USA, Volume II, 348-360.

Verburg, R. M.; Boschsijtsema, P. M.; Vartiainen, M. (2013), “Getting it done: Critical success factors for project managers in virtual work settings", Int. J. Proj. Manag, Vol. 31, 68-79.

Wang, B.; Liu, Y.; Qian, J.; Parker, S. K. (2021), “Achieving effective remote working during the COVID-19 pandemic: A work design perspective", Applied psychology, Vol. 70, No. 1, 16-59.

Webster, J.; Randle, K. (2016), "Positioning Virtual Workers Within Space, Time, and Social Dynamics", Springer: Berlin/Heidelberg, Germany. 


\section{Extended Summary}

\section{A Research on Remote Working and Its Relation With Social and Demographic Variables}

Today, remote working occupies a pivotal role in discussions addressing the future of the work. Also, especially during the Covid-19 pandemic, remote working has been widely experienced all around the world. Due to the requirements brought about by the pandemic, the effects of remote working became visible in our daily and professional lives. Video conferencing applications, new generation document sharing software, and new digital solutions in cloud technologies have accelerated this process. According to a recent study, approximately $56 \%$ of companies worldwide have adopted remote working practices, while $16 \%$ perform all their operations remotely. On the other hand, $52 \%$ of the employees state that they work remotely at least once a week and $68 \%$ at least once a month. As regards McKinsey's research, $20-25 \%$ of employees in developed economies and about $10 \%$ of employees in developing economies work in jobs suitable for remote working five days a week. It is estimated that remote working will be applied more widely after the pandemic than before.

Di Martino and Wirth (1990) defined remote work as the "work carried out in a location where remote from central offices or production facilities, the worker has no personal contact with co-workers there but is able to communicate with them using new technology". The working spaces can be a room of the house, a café, co-working spaces, a park, or even a beach. Access to technological facilities such as mobile smartphones, tablets, portable computers, and wifi connections provide the necessary infrastructure for this working style. At this point, it becomes critical for institutions or companies to have the necessary technological infrastructure and orientation programs for remote working. On the other hand, whitecollar employees must develop their digital and online skills to be productive in the course of remote work.

There are many studies in the literature that draw attention to the positive and negative aspects of remote working. It is often stated that thanks to remote work, the employees can devote more time to their family and private life and can switch to a more independent and flexible working style. In addition, companies or institutions can save money in the absence of transportation and office expenses. On the other hand, some studies emphasize that the workload of employees may increase with remote work. Also, their work-life balance can be affected negatively, and they may experience digital fatigue.

The widespread adoption of remote work implementations and the use of a variety of digital tools during the pandemic has led to the need to investigate the attitudes of employees towards this working style and the various factors that affect these attitudes. In this context, the present study aims to reveal the social and demographic determinants that have an impact on remote work attitude and to make some recommendations about the future of remote work. The study has two main research questions.

RQ1: What are the demographic determinants of remote work?

RQ2: What are the social determinants of remote work?

In order to address these research questions, we collected the data from 415 white-collar and remotely working people in different regions of Turkey by using the questionnaire method. We used the social media and snowball sampling method to reach remote workers and analyzed the collected data with the SPSS 22 package program.

The data collection tool used in the study consists of three sections. In the first section, there are ten questions for demographic characteristics of the participants (sector, gender, marital status, having children, education, job position, age, job experience, weekly working hours, weekly remote working time). In the second section, 6 questions are directed to reveal the participants' remote work experiences (e.g., frequency of working remotely, workload status after working remotely, etc.). In the third section, the "Remote Working Attitudes Scale" is used. This reliable and valid scale consists of 16 items and 4 sub-factors: Positive Attitude, Skill Development, Resistance Against Negative Attitude, and Institutional Support.

According to the gathered data, $58.3 \%$ of the participants are private-sector employees, $56.4 \%$ of them are women and $51.3 \%$ are married. The average age is $34 \pm 6.2$. $51.6 \%$ of the participants have at least undergraduate education, while the remaining participants have a post-graduate level of education. $\% 73.7$ of them are employees and $26.3 \%$ of them hold manager positions. Their average income is $7140 \pm 4078 \mathrm{TL}$. The weekly working time of the participants varied between 10 hours and 80 hours and the average weekly working hour is $41 \pm 10.8$. Weekly remote working time ranged between 2 hours and 70 hours, and the average weekly remote working time is $26 \pm 16.1$ hours.

As a result, we observed that white-collar employees with higher education levels develop a more positive attitude towards remote working. On the other hand, when the workload of the employee increases with the remote working, they tend to employ a more negative approach towards remote working. If the institutions or companies switch to remote working without controlling and balancing the workload, they may face negative consequences. Also, it became clear that a planned, balanced, and technically adequate remote working setup implemented by the organizations has the potential to increase the level of positive attitude. When organizations regulate remote working hours in a balanced and professional way and provide support/training for employees, they tend to develop a positive attitude towards remote working. We believe that this could boost productivity and improve the job satisfaction of the employees.

In future studies, it is possible to analyze remote working attitudes of employees by making a public-private sector distinction and considering varying conditions of the different sectors. Also, we believe that analyzing the experiences of employees during the remote working period with in-depth interviews and conducting comparative international studies can make a significant contribution to the literature in the field. 